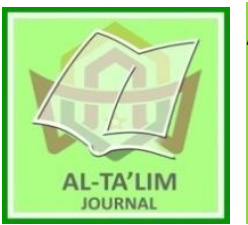

AL-TA'LIM JOURNAL, 26 (3), 2019, (267-279)

(Print ISSN 1410-7546 Online ISSN 2355-7893)

\title{
The Roles of School Principal Leadership in Developing English Teachers' Creativities in Palu
}

Received: $24^{\text {th }}$ September 2018; Revised: $27^{\text {th }}$ October 2019; Accepted: $30^{\text {th }}$ November 2019

Permalink/DOI: http://dx.doi.org/10.15548/jt.v26i3.517

\begin{abstract}
Abdul Gafur Marzuki ${ }^{*}$
Institut Agama Islam Negeri Palu, Indonesia

E-mail: gbudiperwira@gmail.com
\end{abstract}

Saja'un Lampuasa

Tourism Office of Donggala

E-mail: sajaun@gmail.com

\section{*) Corresponding Author}

\begin{abstract}
This research is a descriptive qualitative that explaines and describes any pertinent things related to the school principal leadership and teachers' creativities which occur now at the research spot. This study aims to investigate the roles of the school principal in encouraging, driving, and directing teachers to be creative in performing their works. Results indicated that in encouraging his teachers, the school principal: 1) provides conducive climate and condition by involving his teachers in designing school programs and by welcoming his teachers' comments and arguments on any policies he applies or any decisions he takes; 2) introduces and assures his teachers that education paradigm has changed therefore the school should be managed as a business firm in the area of public services where the most thing that should be considered is how to satisfy customers; 3) informs clearly that in evaluating the staffs' performances he applies reward and punishment policy; and 4) optimizes managerial functions especially in monitoring what happens in the classroom. In driving the teachers, the school primcipal should applies his or her policy and delegates several responsibilities and jobs to the right persons. In directing the teachers he or s lets his or staffs free to do their best.
\end{abstract}

Keywords: School principal leadership; English teachers' creativities; reward and punishment.

How to Cite: Marzuki, A., \& Lampuasa, S. (2020). The roles of school principal leadership in developing English teachers' creativities. Al-Ta Lim Journal, 26(3). doi:http://dx.doi.org/10.15548/jt.v26i3.517

\section{INTRODUCTION}

A school principal has been given a very strategic role in the school that he/she leads especially since the introduction of the concept of the School Based Management and the Kurikulum 13 which basically derived from School Based Curriculum concept have been being put into effect (Fullan \& Watson, 2000; Lingard et al., 2002). To support both concepts, the Indonesian Government, in this case the Ministry of National Education issued a Ministerial Regulation No. 19 year 2007 which stipulated that educational activities which occur at every single educational unit (school) are the principal responsibilities. Those responsibilities are shown in the major roles of a school principal in planning, organizing, actuating, controlling, evaluating the school programs and reporting the school progress to the authorities (School Based Management) (Briggs \& Wohlstetter, 2003; De Grauwe, 2005); in designing and implementing School Based Curriculum which includes determining and formulating school vision, mission and objectives, determining school teaching-learning calendar, determining 
student criteria of success; designing syllabus and assessments, and modeling lesson plan and also in establishing the Management Information System (Supovitz, J.A., 2000; Seli, 2005; Raihani, 2006; Rowland, K.A., 2008).

Through the implementation of both concepts, educational units (schools) are expected to be effective and in turn will improve their performances as a whole and students' achievement in particular (Gamage, D.T. and Pand, N.S., 2003 \& Everard, K.B. et al., 2004). The fact, however, it does not reflect what have been expected. There have been a lot of educational units including schools in Palu that have owned wellprepared planning; good organizational structure and detailed job description; excellent rational programs; well-designed curriculum 13 and posses experience principal and teachers but very few of them can gain high effective school performances especially the students' achievement. There must have been something done in the wrong way. One possibly main factor that causes the low-level of school performance is the lack of teachers' creativities in facilitating students' learning such as creativities in designing and delivering instructional materials and also in providing extra supporting activities outside the classroom. Teachers' creativities are absolutely important in creating effective learning environment for students. The teachers' creativities improvement, however, quite depends on or is very affected by the school principal leadership. In other words, those schools which still have low performance indicate that their school principal leaderships have not been optimum in improving their teachers' existing potentials especially their creativities.

The school principal leadership has an essential role and power in influencing school staff either educational or administrative staff of the school where he/she works (Luo, M. and Najjar, L., 2007). The power includes the ability in giving motivation, detecting, facilitating and making use of individual potential and capacity for the sake of the school business. The strength of the school principal leadership in driving his/her staff to contribute any related capabilities can be seen in the school principal ability in decision making and seeking internal and external supports and source (Botha, 2004; Halawah, 2005; Hallinger, 2005). Besides, the model or the example which is usually demonstrated in the form of clear action and the strong sense of preceding the school needs can also support staff performance in improving school effectiveness.

In relation to the study about the relationship between the school principal leadership and teachers' creativities in supporting school performance improvement, the researchers have conducted initial observation at SMP Al-Azhar as one of favorite junior high schools in Palu. SMP AlAzhar Palu which is established on May $2^{\text {nd }}$ 1992, Basit, 2009 and whose teachers are mostly newly graduated and part-timer, even a few of them are not graduated from teachertraining faculty, has shown several excellent performances, students' achievements in this case, either academic or non-academic achievements, for instance the students' achievement in recent National Exams 2017. The students got average marks 8.14 for Indonesian Language, 9.04 for English, 8.84 for Math, and 8.86 for Science, even there are 3 students got 10.00 in English, 4 students got 10.00 in Math, 5 students got 10.00 in Science. This school in recent years always wins various academic competitions such as Math and Science Olympic, English story telling contest, news presenter contest, either at Palu Municipal level or Central Sulawesi Provincial level, even a few at the national level. While for non-academic performance, the school has been well-known with its tight discipline besides considered as a school which has clean and healthy environment. It also pioneers in making students accustomed of certain habits such as picking any rubbish and put it in provided bin, not keeping or returning anything founded, standing in a line or queuing up for getting meal, and so on. Furthermore, in recent years there have been some of this school graduates enter certain 
outstanding senior high school such as MAN Cendekia Gorontalo in Gorontalo Province, SMAN 17 Makassar and SMAN Tinggi Moncong Goa-South Sulawesi Province. Seeing these phenomena the researchers then assumes that there must have been 'something special' there and that is the strength of school principal leadership.

During the initial observation conducted, the researchers found some teachers' creativities products at SMP Al Azhar Palu, either in the form of non-physic or physic. Non-physical teachers' creativities products reflected from the new students' acceptance process like designing placement test, character building and accustomed program and activities, for instances giving significant psychological awards for those who return the lost items, standing in line or queuing up for meal, welcoming and greeting any visitors warmly and friendly, until the instructional strategies development and other innovative educational supporting programs such as providing Math and Science Olympic talent scouting, Indonesian short-stories writer talent scouting, English story teller talent scouting, English speaking club, English day, English area, English camps, always uttering announcements especially about student affair bilingual (in Indonesian and in English) several martial-arts program, and theatrical group. Physical creativities products can be easily found, for instance, in making into use of information and communication media either printed or electronic such as the providing attracting wall magazine, providing any information about the SMP Al-Azhar program and activities through internet. And there is still one more importing thing that SMP Al-Azhar teachers do in different way that they never give punishment for students who come late promptly after morning school assembly like occurred at mostly other school that the victims cannot join certain classes in the fresh our but later after all learningteaching process over.

Concerning English learning-teaching, the researchers have been impressed so much because every time he is appointed to be one of adjudicators on Palu municipal level of
English Speech or English Story Telling Contest, the contestant from this school mostly wins. These are the reasons why the researcher chose this school, the English teachers and the principal in this case, as subjects of this research.

\section{METHOD}

This research is a descriptive qualitative that explaines and describes any pertinent things related to the school principal leadership and teachers' creativities which occur now at the research spot. It is directed toward determining the nature of situation as it exists at the time of the study.

Since this research was only conducted in a certain place that was SMP AlAzhar Palu and the findings in turn can not be generalized, the design was case-studies as Basit (2009) highlights that case study is a way of organizing social data for the purpose of viewing social reality. It examines social unit as a whole. The unit may be a person, a family, a social group, a social institution or a community. This research was held at SMP Al-Azhar Palu from July till September 2018. As informed previously, before conducting this research, the researcher has been being done the initial observation for about four years because the researcher is often involved in certain provincial contests especially in English story-telling and English speech contests. Besides, the researcher is one of the school committee members since two of the researcher's sons graduated from that school. This gave the researcher chance to access informal observation. The observation focused on the English teachers and school principal performances.

That long enough observation was completed by conducting a well-planned intensive observation for about two months, July till September 2018. Apart from conducting the observation, during the two month-period the researcher collected data related to the research questions by using other techniques.

The wonderful performance of SMP Al-Azhar which indicated by the high 
students' achievements in recent years could not be separated from the teachers' creativities role. One of the major factors that might facilitate the teachers' creativities was the school principal leadership.

In obtaining data, the researcher acted as the instrument and was equipped by certain supporting instruments i.e. observation checklist, guideline of in-depth interview and interview sheet, documentary sheet and field notes. The observation, the real and formal observation in this case, was employed to list what happen during the instructional process, and towards accustomed and extra curricular activities took place by using check list sheet.

The interviews were conducted towards the school principal and teachers to investigate how the school principal leadership improved the teachers' creativities. In accordance with the topic of the research, the researcher chose the English teachers as the respondents. The interviews were held by referring to the provided interview guide line.

Documentary study was employed to check the documents and the records of the available and used administrative teaching preparation such as lesson plans or teachers' notes by using documentary evaluation sheet. Field notes technique was employed to record miscellaneous small but valuable things that could not covered by the previous techniques.

Data analysis technique was determined by kinds of data collected. Since this case-studies research was categorized as a qualitative research, as a rule, a qualitative research uses verbal data and does not use statistical analysis. Data analysis which was employed in this research was descriptive analysis. The descriptions on school principal leadership and teachers' creativities variables, and the relationship between both variables were described respectively.

Before getting described, the data that had been collected through certain techniques were recapitulated and reduced. The data which were closely associated with the research topic after recapitulating and reducing processes were validated by doing triangulation. The triangulation aimed to check and re-check the data validity. In this case, the triangulation was done either toward the different information resources or toward the different data collection techniques. After validity checking, the data were displayed, interpreted, explained and concluded.

\section{RESULT AND DISCUSSIONS}

SMP Al-Azhar Palu is one of the nongovernment or private educational institutions in Palu. It was established on May $2^{\text {nd }} 1992$ and focuses its activities on education service. Even though the school is located in town, it is not situated on a main or crowded road, and there is only a few of public-transportation passing by. The road is named Jalan Tanjung Malakosa, just a block away from Jalan Kartini, one of Palu's main roads with its government and private office-building rows and its crowded public-transportation. Therefore, it is not difficult to get there.

The school is built on approximately 300 square-meters wide. The school building consists of a principal office, a wide enough teachers' room, an administrative staff's room, 15 classrooms, a students-counselor's room, a library, a science-laboratory, a small theater, a student-association's room, a health center room, two wide-enough school-yards equipped by several adequate sportequipments, a small mosque, a studentcanteen, several lavatories, a store-room and the last but not least, a teacher-dormitory which is occupied by several youngunmarried male teachers whom the principal frequently invites to discuss informally with after school. For the time being, the number of students in this school is 484 which are grouped into 15 learning-groups, 5 different learning-groups for each level. Those students are accompanied, taught, guided and trained by 33 subject-teachers; supported by a counselor and 3 administrative staff; and of course led by the most valuable person in the school, the principal.

Data-collecting of this research used observation and In-Depth Interview. The 
focus of observation and interview concerning about teachers of English creativities and roles of the school principal in encouraging, driving and directing them to be creative in providing and delivering teaching materials; and in providing any other extra supporting program, so the main information resources were the school principal and the teachers of English behaviors which previous observed by the researcher either before or during the research conducted.

\section{Teachers of English Creativities}

Based on the observation result the researcher did during July-September 2018, it seemed that there have been a lot of products in the form of educational programs and activities and these indicate that the teachers of English at SMP Al-Azhar are quite creative. The teachers' creativities in improving school performance and students' achievement do not only occur inside the classroom but also out-side the classroom as well.Even a teacher on the interview claimed that accustoming and extra-curriculum programs and activities contribute at least more than a half of the school performances, particularly the students' achievements as he states that Extra and class activities support each other, in the academic class and extra curricular usage, and like the more significant ones are extra activities.

These extra supporting programs and activities indeed make SMP Al-Azhar becomes different from other school in Palu. Time allocated in formal learning-teaching processes in the classroom is enough only for reaching cognitive objectives. For affective and let alone psychomotor objectives need extra time experiences.

As a matter of fact most the teachers of English who teach at SMP Al-Azhar are those ones who have quite good competencies due to the fact that before they were accepted to be teaching staff, they had to take and pass a series of objective and tight selection procedures. Therefore simple things dealt with learning-teaching administration and preparation are not the problem any more like what happen at most schools in Central
Sulawesi. In other words their basic academic and pedagogic competencies have met the standard. The way they teach or the strategies they apply in the classroom just follow the learning-teaching standardized procedures as what occur in other formal schools which aimed to achieve cognitive objectives and focus the teaching-learning materials toward what will be tested in the National Exams.

Teachers' creativities were identified through their Lesson Plan or Teacher's Note as the guidance of their learning-teaching process in the classroom. Most of their Lesson Plans indicated the using of various innovative learning-teaching methods and different interesting teaching media and aids.The Lesson Plan Components showed their creativities and innovations in the teaching steps. Even there were several of the Lesson Plans which indicated the using of multi-methods and multi-media in their teaching/learning scenarios.

Referring to the interviews from 24-27 April 2018, several teachers claimed that the teaching/learning processes have been conducted towards student-centered activities, in other words, the Contextual TeachingLearning Approach has been applied recently and the teachers also have been being attempted to provide and maximize the use of any education resources which are available around the classrooms or school building during the teaching/learning processes. This occurred because the school principal is very concerned on students' learning process and achievement. The following are some teachers' comments:A teacher commentsthat the school principal frequently invites his teachers to watch any films about various creative learning models, strategies, approaches, methods and techniques that have been recommended. Another one commentsthat there have been a lot of profesional trainings for the school teachers about various effective learning methods and the trainers are those who have provincial even national level competences. And for the sake of school improvement, he (the principal)does not hasitate to spend a lot of money on them. 
Several teachers, however, and mostly the young ones are still not satisfied on the school performances especially the students' achievements so far. And this motivates them to make some innovation in the form of classroom action research. Apart from creativities in the classroom, the teachers' creativities could also be seen on their products concerning supporting programs and activities out-side the classroom.

On extra-curriculum program and activities, they focus on affective and psychomotor goals. They teach 'about English language' in the classrooms and they use English as daily communication and forces the students to communicate in English wherever and whenever they meet, and in announcing school programs and activities, policies and any other information which dealing with students' affair. Even they have provided permanent extra-curriculum programs, activities and competitions such as: English story teller talent scouting, English speaking club, English day, English area, English camps, always uttering announcements especially about student affair bilingually (Indonesian and English), school wall-magazine in English, school bulletin in English, website and teachers' blog. Even several students' tasks are provided by using multi-media.

There are two more things that the researcher considers as kinds of creativity because the SMP Al-Azhar teachers including the teachers of English do in different way. First, they never give punishment for students who come late promptly after morning school assembly like occurred at mostly other school that the victims cannot join certain classes in the fresh our but later after all learningteaching process over. This kind of practice is very wise and fair because it does not harm the students. Second, in preparing and couching the students before attending the local and national competitions, not only the subject teachers are involved but also any other teachers. For example: at the time this research was being conducted there was the selection and the preparation of the candidate for the annual English story-telling contest, the teachers who were involved in this activities not only the English subject teachers but also the teacher of stage-performance art. Furthermore, mostly other subject-teachers did not complain about or let alone punished the students who involved in the program and activity due to they did not attend their classes, like what frequently do by other subject-teachers at other school. They believed that those programs and activities were very important and useful for the sake of the students themselves and for the school performance as well. One of important things that sometimes makes someone endures or likes to work for along time at a certain place is exist of mutual understanding and caring among the colleagues.

All of those creativities indeed are not the final objective of the school. As stated previously, everything done by teachers are aimed to reach the final terminal that is the best students' achievement. They do nothing at all if the result can not improve students' achievements. Like in a football game, supposed all the players have presented their best, it useless for the team if the match ended without a winning. In other words the students' achievements are the most significant indicator of the teachers' works. The following are some achievements which have been presented by the students which indicated how successful their English teachers in learning-teaching.

The list of students' achievements on English subject in 2017 National Exams showed how high the achievements are. From 177 participants, there were 3 students got 10; 124 students got $\geq 9 ; 45$ got $\geq 8 ; 3$ got $\geq 7$; only one student got $\geq 6$; and there was only one student who could not pass the decided passing grade.

Furthermore, the SMP Al-Azhar students' achievement on English subject based on theThe 2017 National Exams Achievement Analysis of Juniour High School Level. It is showed that there were only three of 50 test items (no. 46, 39 and 45) which incated the SMP Al-Azhar students' 
achievements below $60 \%$. There were only three test items below the district and national average (46, 39 and 45), and there were only two items below the provintial average. There were four test items which could be answered by 88 students correctly $(3,17,35$ and 38$)$.

The non-academic achievements have been making the school proud, for the last five years (2012-2017 the representatives of Central Sulawesi Province were from this school. And frankly speaking, all of the three 2010 SMA debaters (2 from SMA Negeri Terpadu Madani Palu and 1 from SMA Negeri 1 Palu) who represented Central Sulawesi Province were graduated from this school as well.

\section{The School Principal Leadership}

As stated earlier that the aims of this research were to scrutinize the role of the SMP Al-Azhar principal leadership in encouraging, driving and directing English teachers to be creative in performing their works which in turn are expected to achieve the school objectives, missions and vision. The result of observation and interviews against the school principal and certain teachers on these principal roles described as follows:

\section{Encouraging Teachers to be Creative in Performing their Works}

First of all the significant factors which ease the SMP Al-Azhar principal in encouraging his teachers are the existence of the conducive to working climate and condition at his school. This culture has been intentionally accustomed, well-practiced and well-developed by the principal and all of school personnel. In providing conducive to school climate and condition at his school, the principal involves his teachers in almost all of school affairs according to their kinds of jobs and responsibilities.

The principal involves most of his teachers in designing the school programs by inviting them to discuss the proposed program. The school principal usually thinks over the school programs together with several teachers particularly the vice-principal long and deeply before the formal decision and policy made. The bright ideas for improving school performances which are considered before the principal making decision or policy are not only from the principal himself but also from the teachers. Referring to the observations and interviews during the research took place there were a lot of brilliant ideas which became the school programs were from the young energetic teachers. These teachers mostly live on the school dormitory which provided by the school principal in the school that the principal can easily and frequently invite them to talk informally in their spare time in the afternoon or evening to discuss anything concerning about how to make their school more and more developed. This can be proved by the following principal statement that the principal invites certainteachers according to their responsibilties and jobs to discuss which programs will be taken and he (the principal) acknowledges that there are a lot of brilliant ideas from the teachers he takes beside his own. After having discussion and sharing both side-the principal and the teacher choose the best one.

The teachers' involvements can be also known from the interviewed teachers' point of views. The following are some statements on their involvements: The first statement that the ideas of school programsare even more from teachers than from the principal. The second shows that any ideas either from the principal or from the teachers must be communicated. Both sides-the principal and the teachers contribute approximately fifty-fifty. The third (tc 4) states that the informant always involved in the discussion on any school programs and he then claims that there are some ideas from the principal and some others are from the teachers. It shows that the principal is not allergic towards critics.From all statements it be concluded that almost all of the teachers claime they were involved in designing the school programs and activities, and at the deciding process of which program would be launched, they claimed that the school principal accommodated their ideas. 
Then, the principal welcomes the teachers' comments and arguments against his policies and can be concluded that the principal has accustomed this condition and hopefully to be a culture of school. Even, he does realize that it is very dangerous for the school climate if he does not welcome the teachers' comments and arguments. And as what happens on the school program discussions, in this case, he frequently changes his policies in turn.

The principal eagerness to welcome their comments and arguments can be learned from teachers' point of view as stated that if he does not agree with the certain principal policy or decision he then meets the principal to discuss it and if his argument is reasonable the principal sometimes accept it. The second teacher claimed that if he does not agree with certain principal policy or decision, he goes straight to meet the principal to discuss it and if the principal cannot accept his argument, the principal then explains about it further and at the end he (the teacher) agrees with and follows the rule, however, sometimes the principal accepts and agrees with the teacher's reasonable argument. Secondly, the principal introduces and assures his teachers that education paradigm changes from time to time. In the recent paradigm, a school, especially the private one in which its survival depends on the amount of its students, should be managed as a business firm in the area of services where the most thing that should be considered is how to satisfy customers. Thirdly, the principal informs to his teachers and other staff that for the sake of school performance, in promoting staff he appliesa 'reward and punishment policy', as he describes that Providing information to teachers about 'reward and punishment' but I prefer reward to motivate, for example: every year they are given the opportunity to go to another area with funding from parents or sharing with parents.

\section{Driving Teachers to be Creative in Performing their Works}

In driving his teachers to work maximally, the SMP Al-Azhar principal really applies his policy that is 'the reward and punishment. 'He gives reward and punishment based on the teachers' performances. The forms of 'rewards' depend on how successful the teachers do their jobs. The 'rewards' given are various, from the very simple ones like 'friendly tapping on shoulders" or 'saying thanks or appreciation' on their successfulness in doing their bests as psychological rewards until sending the highly creative teachers to more developed regions or abroad for refreshing and comparative studying. The principal gives the 'psychological reward' objectively considering the teacher characteristics and when the reward will be mostly appropriate to give. For certain performances which can motivate other teachers, the school principal also appreciates by stating his frankly acknowledgements on special occasion like on morning assembly or on flag-hoisting ceremony.

Another reward that the school principal assumes that more significantly impact the teachers is by placing certain teacher to certain position or additional jobs which suitable with his competence and character. It's stated that those who get rewards and become better will have good chances to gain certain responsibilities and positions which are suitable for their competences, school's need and facilities as well. In other words, for gaining significant rewards they need and want, the teachers are demanded to be creative in carrying-out their jobs and responsibilities. The more innovative and effective performances they show, the more significant rewards they will get.In this way, the teachers tend to compete fairly and positively one-another in doing their jobs creatively or innovatively, not just doing their jobs as a matter of routine.

During the observation on JulySeptember 2018, it seemed that the workingspirit of teachers is quite high. According the 5 respondent-teachers, this occurs because they believe and it has been proved that the school principal pays closed attention toward their performances and always gives 
appropriate rewards especially those who are highly creative and innovative. Besides, the fondness of the school principal on 'changes' and 'something new' has been realized and understood by most of the teachers. This understanding drives teacher try to be more and more creative and compete positively to find and show their different own styles in teaching but still on the track of course. Concerning the implementation of 'punishment', the school principal is very careful. He tries to manage that 'the punishment' will not drive them into trouble. This is very rarely happened.

\section{Directing Teachers to be Creative in Performing their Works}

Most teachers who work more then two years at SMP Al-Azhar do understand on how serious and how high their principal expectation toward best school performance, particularly best students' achievements. They have also been accustomed with their principal's character which sometimes looks like easily changeable. This is the main factor that causes their opinions and ideas generally are not different from the principal opinions and ideas, they mostly agree with one-another and of course this avoids them from any long useless argumentations or debates. They agreed directly with the principal mottos: 'quality', 'image' and 'change' and tends to manage his school as a business firm. And that is also the reason why they do not raise objection toward the principal policy which recruits certain teachers who are not graduated from teacher training faculty but own the competence in teaching and training. They also support when they know that the principal spend much money on funding the teacher training or upgrading and the school promotion on mass media.

The positive mind-set and the high motivation of teachers in performing their work at SMP Al-Azhar needed to lead and direct toward the school vision, mission and objectives. The strategy used by the principal is giving the freedom to the teachers to create and to make innovation. The school principal just tries to control and direct and evaluate the creativities. Roles of SMP Al-Azhar principal in developing his teachers of English creativities as expected can be discerned through his ways in encouraging, driving, and directing the teachers to be creative in providing and delivering teaching materials; and in providing any other extra supporting program.

\section{Encouraging Teachers to be Creative in Performing their Works}

As stated before that mostly the teachers who teach at SMP Al-Azhar are those ones who have quite good competencies due to before they were accepted to be the teaching staff, they had to take and pass a series of objective and tight selection procedures. So it can be said that any simple things dealt with teaching/learning administration and preparation are not the problem any more, or in other words their basic academic and pedagogic competencies have met the standard. Therefore, there is no need for the principal to spend much time, energy and money on such things. The only thing that the principal should do is how to encourage, drive and direct those prospective teachers to be creative.

Tracing the result of observation and interviews, the way of the SMP Al-Azhar principal in encouraging his teachers to be creative are as follows: first, the SMP AlAzhar principal provides the conducive to working climate and condition by involving his teachers in designing and in running school programs and by welcoming his teachers' comments and arguments on any policies he applies or any decisions he takes.In involving his teachers the principal invites them to discuss certain program which they concern. From the discussion he admits that there have been a lot of bright and brilliant ideas come from his teachers. Even several teachers stated that the programs and the activities at SMP Al-Azhar are mostly from the teachers.

It is indeed so, in making every important decision particularly concerning about learning-teaching improvement a 
principal should involve teachers and other staff. Their involvement becomes very essential because the school principal can get bright ideas, reasonable arguments and constructive suggestion from various point of views; it also improves decision quality; the principal can also show his/her open-minded disposition by appreciating his/her teachers and other staff on their contributions directly; and the last but not the least, their involvement can bind their commitment in carrying-out the decision. Teachers who have high commitment can be able to think over their students and provide their time and energy to do their job well, even teachers like these will be able to do more than their main and routine jobs.

Besides, involving almost all of the teachers in the process of decision-making particularly in planning and making policy will raise strong sense of belonging. Thissense will in turn trigger high responsibility and spirit for reaching the target successfully. To succeed the programs and activities also need the supporting team-work. Therefore, the principal should welcome or even exploit any participations, helps, assistances or supports from the team. Welcoming teachers' comments on their questioning; or their suggestions, arguments or debate on their refusing towards certain decision or policy is also an absolutely wise strategy. Harmonious relation build in school culture and climate which is based on mutual understanding and trust plus the willingness to accommodate other people reasonable ideas is the most significant and influential factor for school personnel to get what they want. Establishing conducive to school culture and climate is not a simple and instant work which can be completely reached in a short period of time because it can be only thriven on gratified condition. The conducive to school culture and climate mainly depends on individual relationship among school community members and of course the trust, appreciation and consideration showed or given by the principal to his/her teachers, administrative staff and students on their daily life at school. Exploiting school personnel potential depends on how they are treated, inspired and challenged to perform their best, and supported by school resources and of course nurturing and guidance provided by the school principal.

Therefore, a school principal should know how well his/her relation with his/her teachers, administrative staff, students, student parents, school community and surrounding community. This can be usually identified on how the principal realizes their needs and build good mutual understanding in order they can accept reasonable recommendation or suggestion for their performance improvement quality, on how school's personnel feel free in uttering their ideas and know whether their ideas appreciated or not, and on how can he/she assure them to give more valuable rewards as the return of their good performance so far.

In other words in creating conducive culture and working-climate, the principal considers and practices all of the principles suggested by Mulyasa (in Sudrajat, 2008) i.e.: (1) teachers will work harder if what they do are interesting and enjoyable, (2) goals of programs and activities should be wellplanned and well-managed and be informed to all the teacher so that they know what they want to reach, and of course, their involvement and participation from the beginning (planning or in determining target) is a must, (3) teachers should always be informed about how well they perform, (4) giving reward is far better than punishment, however, in some occasion appropriate punishment is needed, (5) trying to fulfill social-psychological-physical need of teachers in order they get satisfied.

Secondly, the principal tries to introduce and to assure his teachers that education paradigm changes from time to time. In the recent paradigm, a school, especially the private one in which its survival depends on the amount of its students, should be managed as a business firm in the area of services where the most thing that should be considered is how to satisfy customers. In short, at school nowadays teachers should 
place their students as customers, as the result, they should provide proper services.

The necessity of possessing customer strategies by an institution will develop its accountability. Accountability means that how far an institution is responsible for its product or its service. The more satisfied its customers, the more accountable it is. Therefore, the application of customer strategy will drive the school improve its performance.Thirdly, the principal informs and explain clearly that in managing the school particularly in organizing and staffing, he applies 'reward and punishment' policy.

Any policy (including 'reward dan punishment' policy) will intensively and effectively be applied just after it has been well-understood by the staff. This understanding includes the background/reason and the goal of every single school policy and decision which have been written or implicitly stated on vision, mission, goal and target of the school. Well-understanding will bring out positive thinking and in turn it will produce well-performance. For the two strategies (the second and the third), a principal should own a special competence in assuring his/her school personnel. Being a school principal someone should know what he wants and expects and why he wants such a thing, and how to express or to communicate the eagerness to school personnel for getting their collaboration, assistances and supports. Lastly, the principal optimizes his managerial functions especially in controlling what happens in the classroom. Since this research focused on the school principal leadership not on management, it discussed the way how the principal controls what happens in the classroom.From the quotations it can be concluded that the way in controlling he uses is very tight but it does not frighten and blame the teachers even though there have been something wrong occurred.

\section{Driving the Teachers to be Creative in Performing their Works}

A teacher is the most influent person in learning-teaching process occurred. Therefore, teacher's creativities in giving his/her quality teaching service are absolutely needed and strongly recommended. In other words, students' achievements are mostly influenced by the strategy, approach, method and technique implemented by the teacher during the learning-teaching process occurred. Since the learning/teaching processes occurred in an institution, the institution leader - the principal should try hard to keep everything happened in the school constantly run as well as possible. For this purpose a school principal should always try to motivate his/her teachers to improve his/her all his/her competences especially pedagogic competence that his/her way of teaching will be getting more and more interesting, significant and joyful, and in turn it will motivate his/her students to learn actively and productively. The school principal in his/her school is like a locomotive for a train, therefore he/she should be able to drive his staff to keep active all the time. In short, like some people say, 'there is no ineffective school, but there is only an ineffective principal. In driving his staff especially the teaching staff-teachers to work maximally, the SMP Al-Azhar principal really applies his policy that is 'the reward and punishment'. The form of reward depends on how successful they do their jobs. This is a very effective strategy. Giving compensation to staff according to their performance and products is one way in treating human resources fairly. The fair compensation will impact well on staff working satisfaction.

Staff is willing to be fairly treated. Therefore all decisions and policies should consider justness before introduced. Any compensation, reward or even punishment will be fairly acceptable if it is based on the job demand and the level of individual competence (performance). The correlation between compensation and satisfaction depends more on the individual perception about justness than on how much compensation he/she get. Therefore amount of compensation given to staff should be based on performance, sort of job, responsibility and risk. So justness here does not mean all staff receives the same compensation. Justness should be the first 
reference in assessing, treating, rewarding and punishing staff. The justness will create conducive working condition, will improve working spirit, discipline, loyalty and stability.

Realizing that there are so many things to do in his/her school, and there are very limited time, energy and it might be his/her own competences, the SMP Al-Azhar principal challenges his staff especially the creative ones by delegating certain jobs and responsibility to the right persons as further reward. Of course, several staff prefers to accept kind of jobs which allow and force them using their competences, and jobs offer and demand various tasks, freedom and feedback on how well they have done their works. Less challenging jobs usually make them boring but on the contrary too much challenging jobs will drive them mad, frustrated and frightened by failure. In other words fairly challenging jobs will cause staff work enjoy and satisfied. Challenging positions and jobs offered which are appropriate with their competence and characters respectively can trigger the teachers to work more maximally. This sometimes occurs because the one who trusted to handle certain position and job tries to do his/her best to get acknowledgement and trust from the authority. Compatibility between an individual personality and his/her competences against his/her occupation or job also impacts his/her work performance since he/she will find out that the job is suitable for him/her.

\section{Directing the Teachers to be Creative in Performing their Works}

Reaching the school targets mostly depends on the school principal' competences as an educational leader in his/her school, because he/she is responsible for organizing and exploiting all resources including and mostly significant, the teachers which are available in the school then direct them to keep focus on the school targets. In directing teachers who have performed creatively, the SMP Al-Azhar principal lets them free to make or do new creation and innovation in providing their best services to their beloved students. He just controls to keep them on the track. This quality control is based on the quality references which have been agreed with.

Directing as a part of controlling is an essential aspect in keeping and driving the program and activity run well. There are a lot of leaders who are very perfect in planning, very effective in organizing and staffing but become fail in reaching their goals due to lack of controlling power, like some wise-words say: 'opportunities make John a thief', 'when the cat is away the mice will play'. So, supposed all staff have own perfect competences and highly motivated, the controlling still is needed to keep them on the track.

\section{CONCLUSIONS AND RECOMMENDATION}

In encouraging his English teachers to be creative in performing their works, the school principal: 1) provides conducive to working climate and condition: (1) by involving his teachers in designing school programs and (2) by welcoming his teachers' comments and arguments on any policies he applies or any decisions he takes; 2) introduces and assures his teachers that education paradigm has changed therefore the school should be managed as a business firm in the area of public services where the most thing that should be considered is how to satisfy customers; 3 ) informes clearly that in evaluating his staff's performances he applies 'reward and punishment policy'; and 4) optimizes his managerial functions especially in controlling what happens in the classroom.

In driving his teachers the principal really applies 'the reward and punishment' policy' and delegates several responsibilities and jobs to the right persons. In directing his teachers he lets them free to do their best. He just accompanys to keep them to focus on the target and controls to keep them on the track. It is a good idea for any educational practitioner particularly prospective school 
principals especially those who are in Palu to read this research findings then visit SMP AlAzhar to confirm and hopefully adopt or adapt the practices. It is also recommended that the SMP Al-Azhar personnel especially the principal to have a look this research findings for self evaluating and for 'pengimbasan' (disseminating). The findings can become references to next researcher who plan to do another research in the area of educational leadership.

\section{REFERENCES}

Basit, A., (2009). The Implementation of an effective classroom management at the second year students of SMP Al-Azhar Palu. Unpublished Master thesis, Graduate School of Tadulako University

Botha, R. J. (2004). Excellence in leadership: Demands on the professional school principal. South African Journal of Education, 24(3), 239-243.

Briggs, K. L., \& Wohlstetter, P. (2003). Key elements of a successful school-based management strategy. School Effectiveness and School Improvement, 14(3), 351-372.

De Grauwe, A. (2005). Improving the quality of education through school-based management: Learning from international experiences. International Review of Education, 51(4), 269-287.

Everard, K.B., Morris, G. and Wilson I. (2004). Effective School Management, Fourth Edition. Paul Chapman Publishing, London: A SAGE Publications Company.

Fullan, M., \& Watson, N. (2000). Schoolbased management: Reconceptualizing to improve learning outcomes. School Effectiveness and School Improvement, 11(4), 453-473.

Gamage, D.T. and Pand, N.S. (2003). Leadership and management in
education.Developing essential skills and competencies. Hongkong:The Chinese University Press.

Halawah, I. (2005). The relationship between effective communication of high school principal and school climate. Education, 126(2).

Hallinger, P. (2005). Instructional leadership and the school principal: A passing fancy that refuses to fade away. Leadership and Policy in Schools, 4(3), 221-239.

Kouzes, J., and Posner, B. (2007). The leadership challenge. CA: JosseyBass.

Lingard, B., Hayes, D., \& Mills, M. (2002). Developments in school-based management. Journal of Educational Administration.

Luo, M. and Najjar, L. (2007). The chineseprincipal leadership capacities as perceived by master teachers. Volume 4 Issue 3.

Raihani, (2006). The principal perspective of successful school leadership in Yogyakarta,Indonesia.

Rowland, K.A.(2008). The relationship of principal leadership and teacher morale, Adissertation, Presented to the ffaculty of the school of education, Liberty University, Unpublished Doctorate Thesis.

Salacuse, J.W. (2006). Leading leaders, How to manage smart, talented, rich, and powerful people, New York: AMACOM, a division of American.

Seli.(2005). School leadership study: Developing successful principals.

Supovitz, J. A. (2000). Manage less, lead more. Principal Leadership 